\title{
O ENSINO DA MORAL NA ESCOLA PRIMÁRIA
}

\author{
ÉMILE DURKHEIM \\ APRESENTAÇÃo E TRADUÇÃo: RAQUEL Weiss ${ }^{1}$
}

\section{RESUMO}

Inédita na França durante mais de oitenta anos e publicada pela primeira vez em português, esta conferência de Durkheim sintetiza sua proposta de uma educação moral de fundamento laico. Trata-se de documento revelador da dimensão normativa do pensamento do autor, central para a compreensão do conjunto de sua obra.

PALAVRAS-CHAVE: Durkheim; educação; moral; sociologia.

\section{SUMMARY}

Unpublished in France for more than eighty years and published for the first time in Portuguese, this conference by Durkheim provides a synthesis of his argument in favor of a non-religious moral education. It's a work that reveals the normative dimension of the author's thought, which is central for the comprehension of his work.

KEYWORDS: Durkheim; education; moral; sociology.

[1] Mestre em Sociologia pela FFLCH-USP, com a dissertação Émile Durkheim e a ciência da moral. Atualmente é doutoranda em Filosofia, FFLCH-USP, onde desenvolve a pesquisa "A teoria moral de Émile Durkheim à luz da filosofia de Kant e do kantismo francês", com apoio da Fundação de Amparo à Pesquisa de São Paulo - Fapesp.

[2] Gautherin, J.La Formation d'une discipline universitaire: La Science de l'education, 1880-1914. Paris: Universidade Paris V — René Descartes, 1991.

[3] Durkheim, Émile. "L'Enseignement de la morale à l'école primaire". Revue Française de Sociologie, XXXIII, 1992, pp. 609-23.

\section{APRESENTAÇÃo}

Enquanto preparava sua tese de doutorado sobre a formação da Ciência da Educação como disciplina universitária, Jacqueline Gautherin ${ }^{2}$ deparou-se com uma grata surpresa. Suas pesquisas nos arquivos da biblioteca da École Normale d'Instituteurs de Paris - atualmente, Institut Universitaire de Formation de Maîtres (IUFM) - levaram-na a descobrir, entre as pastas empoeiradas que guardavam conferências realizadas no início do século XX, um texto inédito de Émile Durkheim. Tratava-se da conferência "O ensino da moral na escola primária”, proferida na École Normale de Auteuil na primeira década do século XX, cujo conteúdo permaneceu desconhecido por mais de oitenta anos, vindo a ser publicado somente em 1992, na Revue Française de Sociologie3. 
Éverdade que vários textos de Durkheim foram publicados postumamente 4 , guardando para si certo ineditismo. Porém, o longo período em que particularmente este ficou submetido à "crítica roedora dos ratos" é algo digno de destaque. É provável que seu desconhecimento se deva à prática de arquivamento de conferências, comum à época. Usualmente, as palestras de pessoas ilustres eram taquigrafadas e, em seguida, datilografadas, para serem encadernadas por assunto, quando, então, eram anexadas aos arquivos da biblioteca. Tais arquivamentos, porém, eram feitos sem qualquer rigor cronológico e sem qualquer tipo de indexação, o que viria a dificultar a localização dos textos, assim como a determinação precisa das datas dos pronunciamentos. É o caso desta conferência que, segundo consta no registro, entrou no arquivo em $1^{\varrho}$ de abril de 1910 . É quase certo, entretanto, que a conferência tenha sido a primeira de um ciclo iniciado no primeiro trimestre ou do ano letivo de 1908-1909 ou do ano letivo de 1909-1910, período no qual Durkheim estaria envolvido com a análise da "História das doutrinas pedagógicas" - tema de um curso ministrado por ele na Sorbonne - e também com a redação de alguns textos sobre a religião.

A despeito das circunstâncias peculiares em que esse texto foi encontrado, o quejá o torna objeto de particular interesse, sua relevância reside também no conteúdo. Trata-se de uma síntese bastante clara, simples e didática de sua proposta de uma educação moral de fundamento laico que, na verdade, diz respeito a um dos aspectos mais importantes de sua obra, aquele que contempla o conjunto de suas proposições normativas 5 . De modo geral, a parte normativa da obra durkheimiana (portanto, inclusive o texto em questão) pode ser entendida como um ponto de interseção entre a parte teórica, que nesse caso se refere especialmente aos conceitos de educação e de moral ${ }^{6}$, a parte empírica 7 , e sua posição ideológico-política, qual seja, a de um "republicanismo liberal".

Sua contribuição no campo da educação transcende os limites da positividade científica, uma vez que avança também no terreno normativo, como no caso dessa conferência, em que Durkheim falou aos futuros protagonistas da nova educação que se pretendia institucionalizar na França. Em relação a isso, é preciso chamar a atenção para o fato de que um dos elementos mais importantes a ser levado em consideração é a constante referência à religião e às analogias realizadas entre Deus e sociedade, argumentos que podem soar estranhos ao leitor contemporâneo, levando a corroborar a tese, bastante difundida, de que a pedagogia durkheimiana teria apenas contribuído para reforçar a heteronomia, característica já presente na educação religiosa.

Uma outra leitura do texto é aquela que procura alinhar-se aos novos paradigmas de interpretação de sua obra ${ }^{9}$, que resulta mais
[4] Conforme pode ser observado pela análise das extensas listas bibliográficas contendo as publicações de textos de Durkheim. Veja-se, especialmente: Karady, Victor. "Bibliographie des oeuvres d'Émile Durkheim”. In: Durkheim, É. Textes. Paris: Les Éditions de Minuit, 1975, vol. 3; e Lukes, Steven. Émile Durkheim - His life and work: a historical and critical study. Londres: Allen Lane, 1973.

[5] Ao contrário do que muitas vezes se imagina, há uma importante dimensão normativa na obra durkheimiana. No caso dos textos relativos à educação, a distinção entre os aspectos positivos e normativos é particularmente importante para uma correta interpretação de seus argumentos. Para maiores detalhes, ver a distinção proposta pelo autor entre "Ciência da Educação" e "Pedagogia": Durkheim, É. Educação e sociologia. São Paulo: Melhoramentos, 1978.

[6] Para maiores esclarecimentos sobre esses conceitos, ver especialmente os seguintes livros de Durkheim: Educação e sociologia. São Paulo: Melhoramentos, 1978; "Educação moral". In: Educação, moral e sociologia. Porto: Res, 2001; A evolução pedagógica na França. Porto Alegre: Artes Médicas, 1995.

[7] No caso, a constatação sobre a dissonância entre modelo educacional vigente e organização social que se pretendia edificar, inspirada nos ideais laicos e racionais da Revolução Francesa.

[8] Essa foi uma tendência demonstrada desde os tempos de sua formação na École Normale Supérieure e que continuou a sustentar aolongo de toda a sua carreira, tanto na esfera propriamente acadêmica quanto na esfera política, em que se destaca sua intensa participação nos debates em torno do "Caso Dreyfus". Em relação a isso, ver especialmente o seguinte artigo: Durkheim, É. “O individualismo e os intelectuais". In:A ciência social e a ação. São Paulo: Difel, 1975.A expressão "republicanismo liberal" foi utilizada por Anthony Giddens para designar a posição política de Durkheim (Giddens, A. "A Sociologia política de Durkheim". In: Politica, sociologia e teoria social. São Paulo: UNESP, 2002). 
[9] Refiro-me aqui aos trabalhos que vêm sendo realizados desde a década de 1980 e que se avolumaram desde a década de 1990 , que têm como objetivo levar em consideração o ambiente social, político e intelectual da época, bem como investigar a obra durkheimiana em todos os detalhes, buscando apreender um conjunto mais amplo das influências recebidas pelo autor e uma consideração mais fidedigna de seu pensamento e de seu projeto acadêmico. Alguns exemplos significativos, dentre os inúmeros trabalhos com este perfil, são os seguintes: Berthelot, J.M.1895 - L'Avènement de la sociologie scientifique. Toulouse: Presses Universitaires du Mirail, 1995; Mestrovic, S. "The social world as will and idea: Schopenhauer's influence upon Durkheim's thought". Sociological Review, no 39, 1988; Mucchielli, Laurent.La Découverte du social. Paris:Éditions la Découverte, 1998; Strenski, I. Durkheim and the Jews of France. Chicago/Londres: The University of Chicago Press, 1994.

[10] Sobre o significado do espírito de autonomia e sobre a maneira de ser ensinado nas escolas, ver: Durkheim, É.Educação moral, op. cit, e A evolução pedagógica na França, op. cit. profícua para o entendimento do pensamento do autor. Com essa perspectiva, o que merece ser considerado são três dimensões implicadas nessa questão. Em primeiro lugar, o esforço do autor em combater a hegemonia da Igreja católica no campo da educação primária, com o argumento de que não seria suficiente realizar um ensino leigo da moral, mas seria imprescindível o ensino de uma moral laica. A segunda dimensão refere-se à tese - desenvolvida em maior detalhe em trabalhos ulteriores - de que a verdadeira origem de Deus não é outra senão a sociedade, o que lhe permitiu mostrar, ao mesmo tempo, a origem humana da divindade e o caráter sagrado que se atribui à moralidade. Finalmente, com esse argumento sobre a analogia entre Deus e a sociedade, o autor pôde também defender que uma educação racional, que revela a origem social da moralidade, é a única que pode forjar nos indivíduos aquilo a que chamou de "espírito de autonomia"10.

No que se refere à estrutura do texto, é possível dividi-lo em quatro etapas fundamentais. Em primeiro lugar, o autor procurou caracterizar a importância da moral, definindo-a como um conjunto particular de regras, as quais possuem valor maior do que todas as outras coisas humanas. Em seguida, defendeu a idéia de que o valor incomensurável dessas regras se deve ao fato de a sociedade ser o verdadeiro fundamento da moral, e por essa razão as regras morais devem ser amadas - não obstante exijam constantes abnegações de nossos desejos. O próximo passo foi afirmar que uma sociedade não pode ter outra moral senão aquela quejá está contida em sua estrutura. Na última parte, procurou explicar como o ensino de uma moral laica poderia ser realizado na prática, sendo afunção primordial da educação formal apresentar meios de justificação racional para as regras morais.

Para concluir, é interessante notar que o caráter de oralidade do texto - lembrando que se trata de uma conferência - datado da última década da carreira do autor, resultou em uma exposição simples e atébastante didática de algumas das principais teses concebidas anteriormente. Dessa forma, essa tradução, que agora chega ao público brasileiro pela Novos Estudos Cebrap, consiste num importante registro do pensamento de Émile Durkheim e, justamente por essa característica de síntese, permite um acesso original a alguns dos principais elementos que estruturam a teoria desse autor clássico da Sociologia. 

mento pedagógico que certamente está entre os mais ousados que já se tentou realizar até o momento. Decidimos ensinar a moral para nossas crianças das escolas primárias em termos puramente laicos. Estou entre aqueles que acreditam que esse empreendimento é necessário e possível. Também estou convencido de que uma revolução como essa não pode ser levada a cabo sem algum sacrifício. Decerto, isso é muito menos simples do que imaginavam aqueles homens de valor e cheios de fé $e^{11}$, a quem, aliás, devemos o grande mérito de ter tomado essa iniciativa. Isso nos explica o porquê, apesar do zelo e do ardor daqueles mestres, de os resultados obtidos ainda deixarem muito a desejar.

Sob diferentes aspectos, essa questão tem sido uma das principais preocupações de toda a minha vida; precisamente por isso é que pensei que esse poderia ser o tema mais pertinente acerca do qual eu poderia me ocupar hoje. Decerto, o problema é demasiado complexo, demasiado difícil, para que seja possível tratá-lo em toda a sua extensão no espaço de uma conferência. Para fazer vocês compreenderem e para justificar o quanto é necessário um método conveniente para o ensino da moral laica, e como tal método deve aplicar-se com todo o rigor às coisas particulares, seria necessário um ano inteiro, ou até mais do que isso. Porém, como me dirijo aqui a espíritos preparados, pensei que, mesmo no pouco tempo de que disponho, não seria impossível fazer ao menos entrever o rumo em que deve ser orientado esse ensino da moral laica na escola primária; pensei que não seria impossível dar a vocês ao menos alguma noção da idéia diretriz na qual o ensino da moral deve inspirar-se. É isso o que tentarei fazer.

Eis aqui como se deve considerar o problema: trata-se de saber como é possível ensinar a moral sem se apoiar em nenhuma espécie de religião revelada, tampouco em qualquer teologia racional. Não que eu pretenda questionar o direito à existência dessas teologias, apenas acredito que as doutrinas metafísicas, evidentemente, não são acessíveis às crianças. Estamos diante da impossibilidade de nos utilizarmos delas na escola primária. Deixemos, pois, tais teorias de lado.

Porém, para que estejamos autorizados a prescindir das religiões é preciso que tenhamos razões suficientes para crer que podemos cumprir \{essa tarefa\} ${ }^{12}$ melhor ou tão bem quanto elas. É necessário que tenhamos motivos para acreditar que somos capazes de prestar os mesmos serviços e, por conseguinte, nossa primeira preocupação deve ser buscar quais são os serviços que as religiões têm prestado, de modo que possamos perceber se estamos em condições de satisfazer às mesmas necessidades, mesmo que de outra maneira.

Enfim, vocês podem compreender que a aliança selada antigamente entre a moral e a religião não pode ser apenas o produto de uma

[11] Provavelmente, Durkheim se refere aqui à personalidades como Jules de Ferry e Louis Liard. O primeiro era o ministro da Instrução Pública, com quem Durkheim teve algumas afinidades e muitas discordâncias, especialmente porque, de acordo com Durkheim, ao invés de haver um ensino leigo da moral, seria preciso instituir o ensino de uma moral laica. O segundo era o diretor do Ensino Superior da França, ardente defensor da idéia de que somente os métodos universais da ciência poderiam oferecer bases sólidas para a reconstrução moral da Terceira República. Foi devido a seus incentivos que Durkheim passou um ano na Alemanha, acompanhando os desenvolvimentos da ciência naquele país.

[12] De agora em diante, as palavras entre colchetes [ ] indicam as correções ou complementações realizadas por Gautherin em virtude de algumas falhas de datilografia no texto original. As palavras que aparecem entre chaves \{\} são complementações introduzidas pela tradução em português, com o objetivo de conferir maior inteligibilidade ao texto na presente versão. Em ambos os casos, tais procedimentos seguiram o rigor de não interferir no teor do que o autor procurava transmitir em seu texto. 
interpretação do homem. Há séculos as idéias morais têm se abrigado nas idéias religiosas e, durante muito tempo, moral e religião foram confundidas. Pois bem, uma afinidade tão estreita entre essas duas espécies de idéias, entre essas duas classes de concepções, deve, evidentemente, corresponder a algo real; deve, evidentemente, em alguma medida, fundar-se na natureza das coisas.

Vou mostrar a vocês o caráter essencial da moral; aquilo que a distingue de tudo o que ela nãoé. O que caracteriza as coisas morais, o que as distingue das demais coisas humanas,éo valor incomensurável que lhes atribuímos em detrimento de todas as demais coisas que desejam os homens. Para nos assegurar disso, deixemos de lado as teorias dos filósofos, deixemos de lado seus livros. Esses filósofos, para serem compreendidos, tentaram reduzir seus sistemas a algumas fórmulas simples, a algumas regras nas quais suas concepções estavam mais ou menos alteradas, para torná-las mais ou menos inteligíveis à massa. Deixemos de lado, pois, a moral dos livros; interroguemos a consciência pública tal como ela fala, tal como ela se exprime ao nosso redor.

Não resta dúvida de que qualquer consciência reta, hoje como outrora, em todos os países e em todos os tempos, tenha atribuído um valor incomparável aos bens morais, não admitindo nenhuma medida comum entre esses bens e os demais bens perseguidos pelo homem. Podemos até admitir que se coloquem sobre os pratos de uma balança os interesses industriais, de um lado, e os interesses da higiene, de outro. Podemos admitir que se faça um balanço entre os interesses da ciência e aqueles da arte. Pode-se fazer, por exemplo, um balanço entre as vantagens de uma reforma sanitária e o seu custo; pode-se verificar se os inconvenientes sanitários de uma prática industrial são compensados por suas vantagens econômicas. Podemos questionar se o estado de estagnação da civilização em um dado país não pode ser compensado pelo progresso da ciência, ou vice-versa.

Contudo, aquilo que não podemos admitir, sem sentir imediatamente ecoar um protesto em nosso interior, é que os progressos da imoralidade possam ser compensados pelos progressos da indústria, ou pelos progressos da arte, ou da ciência. Não podemos conceber que o valor econômico, artístico, científico, de um lado, e o valor moral, de outro, possam ser - em qualquer medida - concebidos como equivalentes. Não podemos conceber que entre essas duas ordens de valor possa haver uma medida comum, e isso porque a própria moral jamais ensinará que a imoralidade pode ser ignorada, compensada por uma vantagem econômica ou científica. A imoralidade de uma sociedade não será menor porque esta pode contar com numerosos artistas, com muitos sábios ou com grandes parques industriais. Por menor que seja o lugar que a moral ocupe na ordem das coisas humanas, nossas consciências devem dar a ela um lugar à parte. 
De onde provém, então, essa importância particular que atribuímos à moral? Analisemos a vida moral do indivíduo. Toda a vida moral do homem é governada por um certo número de regras, de princípios, de máximas, de ações que nos indicam ou nos prescrevem como devemos agir em diversas circunstâncias. A moral é um sistema de regras.

Porém, a existência dessas regras, dessas máximas, que determinam a ação, não é algo particular à vida moral. Não existe profissão que não tenha regras a serem observadas. Todas as classes profissionais têm suas técnicas, ou seja, o código de princípios que consagrou seus procedimentos, que consolidou a profissão. O oleiro que faz os seus tijolos tem sua própria técnica, assim como o médico tem suas regras para com seus pacientes, o professor com seus ensinamentos e o engenheiro em sua fábrica. Toda a nossa vida física está dominada pelas técnicas da higiene e da medicina. Existe um conjunto de regras que devemos cumprir se desejamos permanecer saudáveis ou se desejamos nos curar de alguma enfermidade. Conhecemos essas regras por meio dos médicos, mas nem por isso elas deixam de existir por si próprias. Essas regras, essas leis da técnica profissional, da higiene, têm um caráter próprio, um caráter utilitário: submetemo-nos a elas porque nos tornam saudáveis, porque os testes a que essas regras foram submetidas acabaram por consagrá-las, porque as experiências passadas nos garantem o valor de seu princípio. Os homens se sentiram bem as seguindo durante tanto tempo que temos razões para crer que também nos sentiremos melhor se assim fizermos. Submetemo-nos a essas regras, digo claramente, porque esperamos obter resultados vantajosos dessa submissão. Se nós agimos conforme as regras de higiene, é porque essa é a melhor maneira de prevenir enfermidades; executamos todas as ordens do médico porqueé a melhor maneira de curar uma doença. Em tais circunstâncias a nossa conduta está sempre determinada por uma causa: um resultado desagradável ao qual iremos nos expor no caso de violação dos princípios; agradável se os seguirmos. São sempre considerações utilitárias que nos guiam: é a natureza intrínseca do ato prescrito e suas prováveis conseqüências; é o desejo de ver que esse ato produz resultados [agradáveis].

Tudo é muito diferente no que concerne às regras da moral. Se as violamos, corremos o risco de sermos postos à margem, de quarentena, isolados. Já não falarão conosco da mesma maneira, não nos tratarão do mesmo modo, demonstrar-nos-ão uma estima menor e nos manifestarão até mesmo desprezo. Se a violação é muito forte, a própria sociedade irá nos golpear. Eis as conseqüências desagradáveis de nossa conduta. Porém, é também um fato universal que para que um ato seja moral, para que, enfim, um ato possa ser considerado moral pela consciência pública, não basta que esteja materialmente de acordo com a regra que o prescreve, não basta que seja apenas cum- 
prido o que foi ordenado. É necessário que a ação não se dê por temor das penas, tampouco pelos desejos de recompensa. A consciência moral tem sido sempre unânime a esse respeito: um ato não pode ser considerado moral se o realizamos para evitar penalidades ou para buscar conseqüências agradáveis. Existe aqui algo muito particular. Para que um ato seja moral, ele deve ser levado a cabo de uma maneira determinada. Para que a regra seja obedecida tal como convém que seja obedecida, nós devemos nos submeter a ela não para evitar penas ou para lograr recompensas, mas tão-somente porque a regra ordena, $e$ por respeito à própria regra, porque ela se apresenta a nós como respeitável. Em uma palavra, devemos agir tal como dita a consciência pública, devemos cumprir o dever simplesmente porque é dever, por respeito ao dever.

Vocês perguntam como isso é possível! Constatam somente agora que todo mundo fala dessa maneira. Não me refiro aqui aos filósofos. Porém, vocês também compreendem que, para que assim seja, essas regras precisam ter um prestígio muito particular, uma autoridade excepcional que nos faça nos prostrarmos a sua vontade e que nos imponha obediência. Sim, essas regras morais possuem tal autoridade. Sabemos muito bem em que tom imperativo se manifesta quando fala a voz do dever. \{Ela\} tem um tom autoritário, cortante; não permite dúvida. Na maior parte das vezes, hesitamos diante dos questionamentos sobre aquilo que devemos fazer de nossa vida com respeito a nossa conduta utilitária. Porém, quando se trata do dever, tudo está claro, tudo está nítido.\{Este\} ordena de uma maneira precisa. Para ter uma idéia de seu perfil, é preciso que nos escutemos. Escutem essa voz interior que os homens conhecem tão bem. A maioria dos homens não sabe de onde vem, porém, todos a sentem em si, e quando nós prestamos atenção nessa voz, percebemos que $\{$ esta\} se manifesta de tal maneira que é impossível não reconhecê-la. Podemos até mesmo permanecer surdos a essa voz, porém, não podemos negá-la. \{Ela\}tem um caráter imperativo, ordena, e é isso o que dá segurança às nossas ações quando acreditamos escutá-la claramente. É por isso que alguns filósofos disseram que o dever nãoé senão um conjunto de regras severas, imperativos aos quais devemos obedecer porque ordenam. Entretanto, se a moral não fosse nada além disso, se tivesse apenas exigências desse tipo,é provável que os homens não conseguiriam praticá-la. Se a moral não fosse mais do que mandamentos, perguntaríamos por que os homens hesitam em violá-la.

Para que pensemos em cumprir o dever, não basta que \{este\} nos fale imperativamente; é necessário que os atos que nos ordena possam comover-nos, emocionar-nos. É preciso que o ato reclamado não nos seja estranho, que possamos desejá-lo, que, de algum modo, \{ele $\}$ apareça para nós como algo bom e digno de ser amado. A moral aparece 
para nós como um sistema de princípios imperativos, por um lado. Porém, se nada fosse além disso, poderíamos até não estar de acordo com ela e, mesmo assim, ceder a sua coerção, porém, não poderíamos desejá-la verdadeiramente. Para querê-la é preciso que possamos amála. É isso que compreendeu a opinião comum, quando afirma que na moral coexistem duas idéias, a idéia de dever e a idéia de bem.

Mas o que significa a idéia de bem? Significa que a moral nãoé apenas um sistema de regras, mas que o ato moral é algo bom, que pode serdesejado, que podemos amá-lo. O filósofo Kant intentou, dado que possuía uma alta idéia de dever, reconduzir a idéia de bem à idéia de dever. Entretanto, essa redução é impossível. Não se pode reduzir a idéia de bem à idéia de dever. A idéia de dever tem seu brilho próprio, não se pode violar [velar?] esse brilho a nossos olhos sem que seu horizonte se torne mais ou menos obscuro; é necessário que a moral apareça a nós como amável e digna de ser amada, que fale ao nosso coração e que possamos cumpri-la, até mesmo em um momento de paixão.

Porém, não podemos considerar esta segunda característica enquanto um aspecto da primeira. Desejamos os atos morais como os demais bens, porém, os bens morais se distinguem de todos os demais; podemos amar a honra, a riqueza, a glória; e para obter esses bens, aquilo que deve ser feito é, de certo modo, apenas seguir a inclinação de nossos desejos, deixar que eles nos conduzam. Podemos guiar nossos desejos pela inteligência, conduzi-los com reflexão, mas não é necessário resistir a eles, e não temos mais nada a fazer do que segui-los. Todavia, quando levamos a cabo um ato moral, sentimos certo esforço, fadiga, sacrifício. Vocês bem sabem que os pormenores de nossa vida cotidiana são feitos de sacrifícios a todo instante. A cada momento fazemos sacrifícios; até a vida moral ordinária, cotidiana, supõe esforços desse gênero. Sabemos bem que um ato moral demasiado fácil de ser executado não é um ato moral. Em alguma medida e de qualquer forma que seja, fazemos violência contra alguma coisa quando realizamos um ato moral. Sim, é verdade que seguimos nossos desejos, mas, por outro lado, outros tantos são reprimidos; realizamos uma violência contra a nossa natureza. Ao agir moralmente, elevamo-nos acima de nós mesmos, sentimo-nos superiores. \{Assim\} se não nos violentamos, se decaímos novamente ao nível da vida ordinária, não podemos agir moralmente.

No bem moral existe algo que nos ultrapassa. De qualquer modo que sejam concebidos, os fins morais devem ser representados como transcendentes com relação aos demais bens. Que se represente a moral como um sistema de regras que ordenam, ou como um ideal desejado, tanto em um caso quanto em outro, a moral aparece para nós como algo que nos vincula a um outro mundo, a um mundo que não nos é estranho, sem dúvida, a um mundo que evidente- 
mente nos concerne; porém, trata-se de um mundo que nos transcende infinitamente. De fato, quando desejamos a moral, temos a sensação de que nos elevamos, que dominamos algo em nós. Eis aquilo que faz com que, em todas as épocas, as idéias morais tenham sido tratadas e expressas sob formas religiosas. É difícil realizar um ato moral. Quando agimos moralmente, arrancamos, em alguma medida, alguma coisa de nós mesmos, voltamos nosso olhar para algo que nos transcende, que nos domina. Essa é a razão pela qual as idéias morais precisaram estar envoltas em símbolos religiosos. Os homens têm necessidade de compreender os motivos de sua própria ação, precisam entender por que lutam para atingir esse ideal que, desde sempre, possuiu o mesmo caráter, que sempre ocupou um lugar tão importante na vida social. O que acontecia, em certos momentos, para que os homens estivessem dispostos a esquecer seus próprios interesses, a sacrificar até mesmo sua vida? A que se subordinavam para que esse ideal não aparecesse como uma vaga fantasmagoria de seu espírito? Onde encontrar essa realidade a que se agarravam tão desesperadamente?

A religião ensina que, acima do mundo em que vivemos e do qual fazemos parte, existe um poder moral de outro gênero, que nos domina, que é superior a nós, e do qual dependemos. Porque nos é superior, tem tudo aquilo que é necessário para ser o legislador de nossa conduta, e nós somos apenas seus súditos. É o poder divino. Estamos em suas mãos. Possui toda a autoridade necessária para promulgar-nos a lei. Possui a majestade, e a majestade que lhe reconhecemos explica a majestade da própria lei. A explicação é muito natural. Todavia, em contrapartida, um deus não é apenas um legislador reverenciado, um amo imperioso que nos dá ordens ante as quais nos inclinamos sem mesmo compreendê-las. Um deusé, ao mesmo tempo, um poder seguro que nos ajuda e nos assiste. Foi Deus quem nos fez, diz a religião,é deleque procede nossa existência.É nosso pai, nosso amigo, podemos contar com ele, se estamos de acordo com suas ordens. Tem, pois, tudo aquilo que é necessário para nos governar, tem tudo aquilo de que precisa para ser amado.

E assim a lei moral se encontra unida à pessoa divina; e eis por que os primeiros homens consideraram a lei moral como a própria palavra de Deus. Como conseqüência dessa situação, as regras tomavam de empréstimo uma grande potência moral da qual o homem dependia, por isso deveria submeter-se com amor, deveria agir violentamente contra sua própria natureza e amar a Deus. Assim, o ato moral que lhe era exigido era de seu próprio interesse, pois lhe era reclamado por um ser essencialmente bom, por um poder paternal. E, desse modo, até as crianças podiam compreender de onde provinha esse respeito que lhes era reclamado pela lei moral. 
Eis no que constitui a grande dificuldade da moral laica. O queécomplicado não é encontrar razões bastante laicas para justificar por que tal ou tal modo de agir é recomendável. Aquilo que é muito mais difícil, porém não impossível,é, de maneira geral, fazer com que a criança consiga compreender por que ela tem deveres, por que precisa violentar-se, desprender-se de si mesma para cumprir tais deveres. É necessário que compreenda que existe, acima dela, algo ante o qual deve prostrar-se, regras às quais deve obedecer simplesmente porque ordenam, é preciso vincular tais regras a um poder moral do qual elas emanam; e para que os atos reclamados possam aparecer como desejáveis é preciso que esse poder seja concebido como algo benéfico, como algo bom.

Se renunciamos a nos apoiar em uma potência divina, precisamos encontrar outra força que possa desempenhar o mesmo papel. Sim, existe uma potência da qual a divindade não é mais do que uma expressão simbólica; sim, existe uma potência que está ao nosso redor, dentro de nós mesmos. É tão misteriosa quanto a outra, porém, podemos mostrá-la, fazer com que seja compreendida, que seja percebida com nossos olhos, da mesma forma como podemos perceber o mundo exterior. Essa potência moral, tão real como a potência física, porém, não tão visível,éa sociedade, a sociedade da qual fazemos parte. E, com efeito, uma sociedadeé para seus membros aquilo que um deus é para seus fiéis. Um deus é um poder superior ao homem, que lhe dá ordens, da qual o homem depende. Pois bem, a sociedade tem, com relação a cada um de nós, a mesma superioridade; e essa superioridade não existiria para nós se não a sentíssemos. A sociedade, tal como a divindade, ultrapassa infinitamente o indivíduo, tanto no espaço quanto no tempo. O indivíduo é, pois, um ponto no infinito social. Está perdido nessa imensidão.

Mas, por outro lado, diz-se que as sociedades são mortais. Sim, todas as sociedades são mortais, porém, até mesmo os deuses por vezes têm sido considerados mortais. Entretanto, mesmo se as sociedades são mortais, nãoé menos verdadeiro que sua existênciaé extremamente maior do que a do indivíduo. As gerações passam, a sociedade permanece. Sua vida não se conta por dias, por semanas, por anos; conta-se por séculos. Portanto, também no tempo ela ultrapassa o indivíduo. Assim, pois, um poder moral, ou a coletividade,éo sistema formado por todas as consciências individuais no presente e no passado. Ultrapassa o indivíduo no espaço, assim como o ultrapassa do ponto de vista da riqueza moral. Por conseguinte, nas consciências individuais existe menos civilização, menos moralidade do que no todo, nenhum de nós absorve isso completamente.A ciência, a arte, a religião, todas as crenças, todas as idéias da técnica econômica, industrial, comercial, tudo isso está na sociedade; tudo isso nos ultrapassa, tudo isso nos transborda por todos os lados.

Todas as religiões apresentaram Deus como o legislador da conduta humana. Porém, é a história que nos mostra a realidade, e a rea- 
lidadeéque o autêntico poder legislador dos homens, oúnico,éa sociedade. Quando olhamos a realidade, percebemos também que a moral viveu a vida das sociedades. Cada sociedade teve ou tem a sua moral. Existiu a moral grega, a moral romana. A moral evolui no espaço, do mesmo modo que evolui no tempo. Antes se dizia: a moral grega, a moral romana, não se parecem com a nossa, porém, isso se deve ao fato de os espíritos das pessoas daquele período não estarem suficientemente abertos: não conseguiam enxergar onde estava a verdade.

Pois bem, a história não nos permite admitir semelhante tese.Seos romanos possuíam uma moral diferente da nossa, \{isso\} não era absolutamente uma conseqüência de algum erro deles, de sua cegueira. Não, \{eles\} simplesmente não podiam ter outra. Dada a organização da cidade romana, a moral não podia ser diferente daquilo que era. Os romanos não poderiam viver com outra moral. Sim, se por acaso alguém pudesse ter infiltrado algumas de nossas idéias no espírito dos romanos, a cidade romana não teria sobrevivido. No dia em que as idéias morais se transformaram, o Império Romano ruiu. $O$ papel da moral é fazer com que os homens vivam juntos, e não provocar a sua morte. É somente porque, em um dado momento, não eram possíveis sociedades senão desse gênero; também não era possível uma moral senão desse gênero. Se a sociedade romana não tivesse existido, hoje estaríamos acomodados a esse fato.

Entretanto, em grande parte, é daí que provém a nossa civilização. Se esse elo da cadeia histórica tivesse faltado, a própria história não teria sido aquilo que foi. Não é por azar, ou por um capricho do homem, que a moral se transformou. Não, isso ocorreu porque dada uma sociedade, não poderia existir mais do que tal moral. Se me apresentam o modo como entendem o matrimônio, a família, em uma sociedade, eu poderei dizer a vocês qual era a moral dessa sociedade, pois tudo está intimamente ligado.

Nossa moral está vinculada a nossa organização social, da mesma maneira que a moral romana estava ligada à organização social da cidade romana, assim como a moral grega era um produto da sociedade grega. Releiam o admirável e sempre atual livro de Fustel de Coulanges: $A$ cidade antiga, e se convencerão disso. É a sociedade que institui a moral, pois é ela que a ensina. Mesmo que se suponha ser possível demonstrar a verdade moral fora do tempo e do espaço, para que tal verdade moral chegue a se tornar uma realidade, será preciso que existam sociedades que possam adequar-se a ela, que a sancionem e que a tornem realidade. Para que exista a justiça que pedimos, é mister que existam legisladores que a façam penetrar nas leis. A moral não é uma coisa de livros; brota das mesmas fontes da vida e chega a ser um fator real da vida dos homens. Não existe senão na sociedade e pela sociedade. 
Aí está, pois, um aspecto da divindade que encontramos na sociedade. Esse é o grande poder moral que possui a sociedade: sentimos que ela nos comanda; toda a legislação moral provém dela. Um deus não é somente um amo respeitado, um amo temido, é também um poder seguro, benfeitor. Pois bem! A sociedade preenche também tal condição. A sociedade, por um lado, também nos domina, ultrapassanos, dá-nos ordens. A todo instante nos incomoda, pede que façamos sacrifícios por ela. Dessa forma, aparece para nós como um grande poder dominador.

Porém, ela não está fora de nós por completo: também está em nós. Não está verdadeiramente viva e não é real senão nas consciências particulares. Está dentro de nós e fora de nós. É a melhor parte de nós mesmos. Tudo aquilo que existe em nós de autenticamente humano provém da sociedade, tudo aquilo que constitui a nossa consciência, enquanto homens, vem da sociedade. A linguagem é um produto da sociedade que, tal como a moral, expressa uma das fisionomias da sociedade. Aprender palavras não é somente aprender sons, é também aprender idéias. Um dicionário contém toda uma maneira de pensar. Em uma língua existe uma mentalidade própria. Aprendendo uma língua, armazenamos todo um sistema de idéias que expressam a realidade e todo um conjunto de maneiras de ver as coisas.É aprendendo a língua materna que se forma o nosso espírito. A língua nos vem da educação social.

Outra escola na qual nos formamos é a ciência. Aqui vocês recebem uma cultura científica. Portanto, sabem como se forma o espírito sob a ação da ciência. Além disso, mesmo aqueles que não recebem diretamente essa cultura, mesmo aqueles que estão privados de toda cultura científica, sem nenhuma dúvida, beneficiam-se dela. A ciência elabora conhecimentos para todos, e o conhecimento produzido por uma pessoa chega a ser propriedade de todos. A geometria nos ensinou a fazer coisas, a trabalhar de certo modo; a noção de causa nos foi dada pela ciência; todas as grandes noções, todas as noções essenciais que adquirimos a cada dia, adquirimos na escola da ciência. Retirem de nosso espírito tudo aquilo que adquirimos pela linguagem, pela ciência, o que restará? Retirem da mesma maneira aquilo que provém da vida afetiva, pensem nesses vários sentimentos familiares, aqueles vários sentimentos morais que possuímos. Sempre permanecerá em nós o amor maternal, paternal, dir-se-á. Errado! Houve certas sociedades em que tais sentimentos não existiam, em que não existia o amor paternal. Não sei se existe um único sentimento no coração do homem que não provenha da sociedade. É a sociedade que desperta esses sentimentos, segundo o tempo, segundo os lugares, segundo as condições. Os sentimentos evoluem incontestavelmente. 
Percebam como nosso espírito é produto da ação social. E não é somente no primeiro período da vida, quando a sociedade penetra em nossa vida interior, ou quando somos adultos. Na verdade, essa ação continua consolidando perpetuamente a obra edificada. Se não o fizesse, se não prosseguisse, a obra social desmoronaria. Nossa organização, uma vez formada, tem necessidade de sustentar-se sempre. $O$ ser moral que a sociedade cria em nós, se não tivesse continuamente uma reparação de suas perdas, tal como os alimentos reparam as perdas de nosso corpo, enfraquecer-se-ia e morreria. Pois nós trabalhamos, mesmo que nos desgastemos. Porém, não podemos nos desgastar sem antes termos recebido um suprimento. É necessário que o gasto do nosso organismo físico seja equilibrado para que permaneça saudável. E o mesmo ocorre com o nosso organismo moral. Os esforços que fazemos para trabalhar bem implicam um desgaste. Para sustentaressa fadiga, a todo momento chegam até nós elementos que vêm de fora, sem que sequer suspeitemos disso. Existe um afluxo de forças que nos reconfortam perpetuamente, sem que nos demos conta. Assim, não podemos agir sem a aprovação de nossos semelhantes, sem o assentimento da opinião pública.

Sem dúvida, podemos resistir a ela, porém, isso não nos leva a lugar algum, só nos faz perder vantagens. Estamos obrigados a tirar unicamente de nós mesmos as forças para uma nova luta. Quando sentimos que estamos de acordo com nossos contemporâneos, somos penetrados por sentimentos que percebemos vir da própria sociedade. Sentimo-nos mais fortes e, na verdade, somos mais fortes. São forças reais, mesmo que não possam ser medidas no dinamômetro. Somos realmente mais fortes. Não temos necessidade de ser sustentados, animados, é uma ação permanente, porém, a sentimos especialmente nas épocas críticas, quando estamos particularmente abatidos, desanimados. Se nos reunimos a um grupo ao qual estamos ligados, imediatamente nos sentimos recuperados. É nessas ocasiões que se percebe a utilidade da família, das associações, das festas e das cerimônias públicas. Para que servem tais manifestações? Servem para manter os sentimentos coletivos da sociedade, reunindo as massas, convidando-as a reviver esses sentimentos, expressando-os de maneira comum. Vocês sabem como esses sentimentos ficam exaltados quando os indivíduos estão reunidos. Os partidos políticos bem que percebem isso. Buscam todas as ocasiões de agrupar os indivíduos para reconfortá-los, para exaltar seus sentimentos. Nossa vontade é, então, aumentada pelo grupo. Existe, sem que vejamos com clareza de onde provém, uma fonte perpétua de força que nos sustenta incessantemente e sem a qual não conseguiríamos resistir.

Assim vocês podem compreender como a sociedade, enquanto um poder legislador, é também um poder acolhedor, uma fonte de força,e 
por isso devemos amá-la, é dela quevem, em parte, a nossa vida. Rebaixaríamos ao nível da brutalidade, se retirássemos tudo aquilo que a sociedade fez por nós. Retirem a linguagem, e não restará mais do que sensações da vida animal; já não existirão \{sequer\} idéias gerais. Todas as formas superiores da atividade humana são de origem social. A religião havia compreendido isso muito bem. Eu falo aqui em termos laicos aquilo que foi ensinado nas Igrejas: existe no homem uma parte eminente que o transcende, uma centelha divina; é a alma, expressão simbólica de uma realidade. Existe algo em nós, uma parte eminente, excelente, que nos transcende, que está acima de nós. Essa parte é justamente aquilo que a sociedade desenvolveu. Pois, o que seria do Homem sem a sociedade? Se não houvesse sociedade, o Homem não seria humano. Na verdade, não podemos saber o que seria do Homem fora da sociedade. Agora vêem como podemos desejar a sociedade mesmo que ela nos dêordens, pois querê-la é querer-nos, negá-la seria negar-nos: nossa sorte está ligada a sua.

Se eu não estivesse pressionado pelo tempo, mostraria o paralelismo entre a noção de sociedade, por um lado, e a noção de divindade, por outro. Um deus é necessário a seus fiéis, porém, esse deus também tem necessidade de seus fiéis, pede oferendas e sacrifícios. Um deus morreria se não se levassem sacrifícios a seus altares. As religiões de hoje são mais idealistas do que aquelas mais antigas, no entanto, esse Deus que se adora hoje também tem necessidade daqueles que o adoram, da mesma maneira que os deuses de outrora. Se o deus cristão não fosse adorado, se não rezassem a ele, certamente ele não existiria.\{Ele\} existe somente porque rezamos. Nós lhe conferimos existência, damo-lhe existência tal qual a obtemos dele. Encontramos esse mesmo círculo na vida social. O indivíduo precisa da sociedade. Mas, por [outro] lado, está claro que a coletividade não seria nada sem o indivíduo. Precisamos da sociedade, porém, ela também precisa de nós. Algumas vezes, quando se apontava aquilo que existe de superior no indivíduo, costumava-se afirmar: a sociedade não existe senão na consciência individual. Mas o que prova isso? Absolutamente nada.

Aqui existe um círculo do mesmo modo que existe um círculo da vida. Existe um certo elemento de mistério, que estamos habituados a sentir com a divindade, mas que encontramos também se nos voltamos para a sociedade. Que partes da sociedade podemos enxergar? Não percebemos mais que alguns poucos elementos: aqueles que estão reunidos ao nosso redor. Sem dúvida, nesse preciso momento, existem à nossa volta uma grande variedade de murmúrios que podemos escutar e que chegam de todas as partes, que nos penetram. Tudo isso é o eco de uma imensa vida em comum, da qual não conhecemos mais do que uma pequena parte. Escutem! É o enorme rumor surdo, confuso, dessa grande máquina social! Entretanto, não podemos 
senti-lo senão de uma maneira misteriosa, pois essa potência que se agita é vaga e misteriosa! Cada vez mais estou convencido de que à base da divindade não existe outra coisa que o poder da coletividade expresso por meio de símbolos. Imaginava-se que os deuses antigos eram poderes físicos. Esse argumento não é sustentável; bem sabem que além da força física existe uma outra que nos afeta de maneira mais próxima: esse grande poder é \{o poder da\} moral, do qual falamos. E Deus, os deuses, foram primeiramente conhecidos como poderes morais. Existe toda sorte de razões para supor que a potência divina é a sociedade personificada, hipostasiada.

A sociedade pode desempenhar na vida moral o mesmo papel que as mitologias atribuíram aos deuses de todos os tempos. São as sociedades que representam o papel dos deuses. Podemos substituir o poder religioso pelo poder político, pelo poder social. Essa substituição é totalmente legítima. Não se faz mais do que colocar as coisas em seu devido lugar. Dessa forma, substitui-se o símbolo pela realidade que ele expressava, mas que a distorcia ao exprimi-la.

Assim, o ensino da moral se torna possível. Já não se trata de uma educação puramente livresca. O ensino da moral consiste em fazer com que se enxergue uma realidade, em fazer com que essa realidade possa ser tocada com as mãos. Ensinar as ciências é ensinar algo real. Ensinar a moral é demonstrar como a moral se relaciona com algo real. Com demasiada freqüência, essas idéias tiveram de ser deixadas no ar, sem que fosse possível perceber com o que estão relacionadas. Com efeito, essa realidade existe e vocês podem fazer com que as crianças sejam capazes de enxergá-la. Existe aqui um mundo inteiro, queé muito ignorado, um mundo no qual vocês devem fazer com que as crianças consigam penetrar. Nós as fazemos descobrir o mundo físico, porém, nada lhes dizemos sobre o mundo social. Podemos utilizar a História para lhes mostrar os laços que nos unem a esse mundo. Esses vínculos dominam nossa vida, contudo, não são laços materiais que podem ser tocados. Nem sempre podemos senti-los, às vezes até negamos sua existência. É preciso abrir os olhos do pensamento, que farão ver como os homens estão sujeitos a algo para além deles mesmos, e isso pelo simples fato de que vivem juntos. Não há ensinamento mais importante.

Eis aqui como um ensino que está vinculado à vida real é capaz de preparar a formação inicial dessa idéia moral. Deve-se mostrar à criança como ela é diferente quando está em grupo e quando está sozinha. Deve-se fazer com que a criança perceba como, estando com seus companheiros, \{logo\} recupera o ânimo quando está desanimada, e que quando está sozinha não \{acontece $\}$ a mesma coisa. Existe sobretudo o ensino da História que deveria servir precisamente para demonstraro queéessa realidade social.\{Por meio da História\},épos- 
sível mostrar como eram os homens antigamente, como estavam reunidos em grupos, como cada geração determinou a geração seguinte. Desse modo, a criança poderá descobrir um mundo novo para ela, poderá enxergar um passado para o qual os seus sentidos ainda não foram exercitados.

Até mesmo o ensino das ciências pode contribuir para isso. Pois, não acreditem que o homem é o único a viver em grupo. Todo o universo não é mais do que uma imensa sociedade da qual cada corpo celeste é uma porção. O átomo atrai o átomo, a célula atrai a célula. Já foi dito que o corpo humano não é mais que uma associação de células. Essa lei dos grupos domina o universo inteiro. Essas são idéias bastante simples, não têm nada de complexo; portanto, podem ser apresentadas sob uma forma elementar. Toda a educação deveria tirar proveito dessas idéias. Se não procedermos assim, não há nada que se possa fazer no ensino da moral.

Para que o ensino da moral seja possível, é preciso manter intacta a noção de sociedade. É preciso conservar a idéia de que a sociedade é a condição mesma da civilização e da humanidade. E uma vez que a pátria não é mais que a sociedade mais altamente organizada, vocês podem perceber que negar a pátria não é apenas suprimir as idéias recebidas, mas é danificar a vida moral em sua própria fonte.

Sem dúvida, há quem acredite que é possível opor a pátria à humanidade. É o resultado de um erro imenso. O grupo altamente organizado, o mais elevado que existe, é a sociedade política, ou seja, a pátria. Seguramente eu conheço muito bem quais são os nobres sentimentos que estão na base dessa negação da pátria. Como a máquina social é uma máquina muito pesada, ela não evolui sempre de acordo com os nossos desejos. A sociedade, tal qual ela é, aparece como um obstáculo para aquelas almas ardentes, plenas de um ideal. Nada mais humano que querer superar esse obstáculo. É assim que, sob a influência de sentimentos generosos, chega-se à conclusão de que a sociedade atual é um inimigo que deve ser vencido e do qual é preciso desfazer-se a qualquer preço. Não tentarei refrear em vocês esses ardores generosos, se os experimentam. Creio, ao contrário, que não há motivo algum para refutá-los arbitrariamente, mas, se por acaso esses ardores tiverem algo de excessivo, eu me remeto à própria realidade para trazê-los, mesmo que demasiado tarde, à moderação necessária. Não se trata de protestar contra esses sentimentos, mas o que quero que compreendam é que esses sentimentos são demasiado violentos e se voltam contra eles mesmos.

Mas, em suma, quem cria essas novas idéias? É a sociedade. É preciso que os homens se interessem por ela para que existam tais idéias. É somente a ela que podemos pedir a justiça mais alta a que aspiramos. Se intentamos destruir nossa pátria, negá-la, intentamos destruir o 
Recebido para publicação

em 20 de agosto de 2006.

\section{NOVOSESTUDOS}

CEBRAP

78 , julho 2007

pp. 59-75 instrumento necessário para as transformações que almejamos. Essa almejada destruição da pátria, nem sempre foi um sonho. Isso já foi levado a cabo em tempos passados. Houve um momento em que todas as pátrias soçobraram. As sociedades que formavam o Império Romano destruído pelas invasões dos bárbaros não sucumbiram. Porém, o que resultou dessas divisões ao infinito? Um imenso retrocesso da civilização.AIdade Média não foi mais que um período de trevas. A destruição da pátria não teria outro resultado. Não sei se será possível impedir que se produzam violências, elas desempenharão, quem sabe no futuro, o mesmo papel que desempenharam no passado, porém, ainda mais feio. É possível que mais cedo ou mais tarde haja uma nova Idade Média, todavia,é mister que seja menos extensa, menos tenebrosa do que a nossa.

A sociedade presente $\{$ deveria\} sabe $\{\mathrm{r}\}$ amar a sociedade de ontem e a de amanhã, queé aquela que a sociedade de ontem e a de hoje carregam em seus flancos. E se o parto é doloroso, trabalhoso, essa é uma razão para ajudarmos em seu trabalho e não nos colocarmos contra ela. É preciso amá-la com suas misérias, pois, como ela sustenta o nosso ser moral por todas as nossas entranhas, suas misérias são também as nossas misérias, seus sofrimentos são também os nossos sofrimentos. É impossível que nos deixemos levar contra ela por um arrebatamento violento sem que com o mesmo golpe nos causemos feridas e nos desgarremos de nós mesmos. 